\title{
DIVERSITY ASSESSMENT OF GRAPEFRUIT (CITRUS $\times$ PARADISI) AND TANGELO (CITRUS $\times$ TANGELO) UNDER INDIAN CONDITIONS USING PHYSICO-CHEMICAL PARAMETERS AND SSR MARKERS
}

\author{
AHMED, S.* - RATTANPAL, H. S. - SinGH, G. \\ Department of Fruit Science, PAU, Ludhiana, Punjab, 141004 India \\ *Corresponding author \\ e-mail: shahnawazpomol@gmail.com \\ (Received 24 $4^{\text {th }}$ Apr 2018; accepted $5^{\text {th }}$ Jul 2018)
}

\begin{abstract}
In a previous report, grapefruit (Citrus $\times$ paradisi Macfad.) and tangelo (Citrus $\times$ tangelo J.W. Ingram \& H.E. Moore, 1975) landraces from diversity rich Indo-Gangetic Plain and arid regions of India were characterised using specific SSR markers. Eight grapefruit and two tangelo varieties were compared with germplasm of diverse origin comprising of cultivars, landraces and wild types. Significant differences were observed for different morphological characters studied. The highest phenotypic coefficient of variance (PCV) and genotypic co-efficient of variance (GCV) were determined for seed weight (104.4 and 103.7, respectively), number of seeds per fruit (102.3 and 101.9, respectively), number of fruits per tree (60.0 and 60.0, respectively) and acidity (40.4 and 38.8, respectively). These mentioned characters were more influenced by environment than other characters. A total of 75 alleles were amplified by 26 polymorphic simple sequence repeat (SSR) loci and the number of alleles ranged from 1 to 4 with an average of 2.88 alleles per locus. The highest number of alleles per locus was four as amplified by CAT01, CS05, CCSM204, CCSM70, CIBE5156, ATC09 and CMS26 followed by three alleles per locus each by CCSM77, CCSM156, CL11, OP29, CMS46, CMS09, CIBE4728, CMS3O and AG14 and the remaining markers amplified two alleles. The highest number of alleles among grapefruit varieties was found in Ray Ruby (75) while the lowest number of alleles was found in Flame (61) while among tangelo varities the highest number of alleles was found in Pearl (64). Average polymorphism (\%) of all the polymorphic primer pairs across all the varieties of grapefruit was 69.55 and the highest polymorphism among grapefruit varieties was found in Marsh (82.09) while among tangelo varieties the highest polymorphism was found in Pearl (81.25). The measure of allelic diversity that is PIC value ranged from 0.17 (CS06) to 0.75 (CAT01) with an average value of 0.53 .
\end{abstract}

Keywords: citrus, germplasm, morphological characterization, molecular markers, polymorphism

\section{Introduction}

Citrus is a sub-tropical fruit that belongs to the family of Rutaceae. It is grown commercially throughout India and is known worldwide of its characteristic flavour, attractive evergreen foliage and flower as well as the extraordinary fragrance, which are added aesthetic values (Rabha et al., 2013). In India, it is grown in acreage of 935 thousand hectares with the production of 11515 thousand MT and productivity of 12181 MT/ha respectively (NHB, 2016).

The grapefruit (Citrus $\times$ paradisi Macfad.) originated from Barbados in the Caribbean islands, is a natural hybrid between pummelo (Citrus maxima (Burm.) Merr.) and sweet orange ( $C$. sinensis L. Osb). It was first named as Citrus paradise Macfad. by James Macfadyen in 1837 (Scora et al., 1982 and Scora, 1988). The tangelo (Citrus $\times$ tangelo J.W. Ingram \& H.E. Moore, 1975) probably originated in southeastern Asia over 3,500 years ago. Tangelo is most likely a result of insect cross pollination of the mandarin orange and the pummelo (pummelo is the ancestor of the grapefruit). 
Grapefruit is the fourth most important citrus fruit economically in the world. It is rich in various nutrients, phytochemicals, vitamin $\mathrm{C}$ and fiberpectin with pink and red hues that contain the beneficial antioxidants lycopene (Silver et al., 2011). There are many benefits of this fruit worth mentioning: (i) peel and seed extract of grapefruit have antifungal properties (Okunowo et al., 2013), (ii) it helps in lowering cholesterol (Platt, 2000) and also (iii) in animals cell studies, grapefruit powder, limonin and naringenin decrease growth and increase self-destruction of colon, mouth, skin, lung, breast and stomach cancer (Chidambara et al., 2011). Citrus varieties show more diversity in their morphological traits such as size and shape of canopy, color, type, number of seeds, fruit weight, fruit diameter, flower diameter, TSS, acidity etc. Generally in plants, the diversity at the phenotypic level is much larger than at genetic level, as selectively neutral molecular markers are used to evaluate the extent of genetic variation.

For future variety management and conservation purposes this adaptive genetic diversity represents important potential. Recently researchers (Amara et al., 2011; Ahmed et al., 2012; Jianfeng et al., 2012; Uzun and Yesiloglu, 2012), have observed the significant diversity among cultivated genotypes of Citrus genus in respect of physiological, morphological and agronomic traits but very little DNA variation has been detected using DNA-markers. Likewise, in other cases markers were used to determine genetic diversity, characterization and phylogenetic relationships among the Citrus and related genera (Gulsen and Roose, 2001; Shahsavar et al., 2007; Uzun et al., 2009; Marak and Laskar, 2010; Golein et al., 2011). Grapefruits are highly polyembryonic and have low genetic variation due to nucellar and mutation origin (Fang and Roose 1997 and Corazza-Nunes et al., 2002). Substantial genetic variation among citrus species and cultivars is due to frequent bud mutation, interspecific and intergeneric hybridization, apomixes and long history of cultivation. There is an urgent need for diversification of scion citrus cultivars for Punjab citriculture for reducing the high risks associated with the outbreaks of new and more severe diseases and pests. Secondly, there is more variation in characters in citrus than in other fruit crops (Reuther et al., 1967) and citrus is phenotypically the most heterogeneous group (Moore, 2001). In the present study ten varieties of grapefruit and tangelo were studied with the aim (a) to correlate the physico-chemical variation with the genetic diversity (b) to estimate genetic polymorphism and relationships among grapefruit and tangelo varieties based on SSR markers.

\section{Materials and methods}

\section{Plant material}

In this study we investigate eight grapefruit and two tangelo cultivars (Table 1) from the College Orchard, Department of Fruit Science, Punjab Agricultural University, Ludhiana, India in the year 2015-16. Observations were recorded for different morphological characters at different growth and development stages. All the trees received recommended doses of fertilizers and other cultural practices during the course of these investigations.

\section{Morphological evaluation}

Morphological evaluation was carried out for two years, i.e. from 2015 to 2016. Fruits were harvested at full maturity, yield and quality parameters data were recorded. 
Characterization of grapefruit and tangelo cultivars was conducted on ten genotypes on the basis of IPGRI (International Plant Genetic Resources Institute) citrus descriptors (Anonymous, 1999). Twenty fruits were sampled from each cultivar for quality analysis, and characteristics evaluated including number of seed per fruit, peel thickness, fruit weight, fruit size, juice content, peel content and rag content. Juice was filtered through filter paper, thereafter, juice samples were examined to determine the following parameters; $\mathrm{pH}$, total soluble solids (TSS), titratable acidity (\% of citric acid) using $\mathrm{N} / 10 \mathrm{NaOH}$ and phenolphthalein as indicator, using digital refractometer, and ascorbic acid (mg/100 ml of juice) using a dye (2, 6-dichlorophenol indophenol) according to the standard method (Rangana, 1986). Design of experiment was in randomized block with five replications. Data were subject for analysis of variation to one way ANOVA. Statistical analysis was performed using analysis of variance. $\mathrm{P}$ values $\leq 0.05$ were considered as significant. A cluster analysis was performed using the unwieghted pair group method with arithmetic average (UPGMA) based on simple matching coefficient in NTSYS software. The phenotypic and genotypic coefficients of variation were calculated as per formula described by Burton (1952) and Burton and de Vane (1953). Heritability, in broad sense, was calculated as suggested by Allard (1960) and genetic advance percent of mean was calculated following the method suggested by Johnson et al. (1955).

Table 1. Citrus paradisi Macf. cultivars and variants used in the study of germplasm characterization

\begin{tabular}{c|c|l}
\hline S. no. & Varieties & \multicolumn{1}{c}{ Origin } \\
\hline \multicolumn{3}{|c}{} \\
\hline 1 & Flame & Originated in Florida - budwood registration program, winter haven in 1988 \\
\hline 2 & Foster & $\begin{array}{l}\text { Originated as a branch sport of a selection called 'Walters' in Florida, USA in } \\
1907\end{array}$ \\
\hline 3 & Marsh & $\begin{array}{l}\text { Originated as seedling trees on the property of a Mrs. Rushin near Lakeland, } \\
\text { Florida, USA (1862) }\end{array}$ \\
\hline 4 & Ray Ruby & Originated in Texas in 1985 \\
\hline 5 & Red Blush & $\begin{array}{l}\text { Originated as sports-lower branches-growing out of 'Thompson' trees in } \\
\text { USA in 1929 }\end{array}$ \\
\hline 6 & Rio Red & Originated in Texas in 1985 \\
\hline 8 & Ruby Red & Originated in Texas in 1988 \\
\hline 9 & Star Ruby & $\begin{array}{l}\text { Originated as a lower branch mutation bearing red-blushed fruits, noticed on a } \\
\text { 'Foster' tree at San Benito, Texas, USA in 1930 }\end{array}$ \\
\hline 10 & Minneola & Produced at John Carpenter, USDCS, Indio CA in 1961 \\
\hline
\end{tabular}

\section{Isolation and purification of genomic DNA}

Genomic DNA was extracted from $5 \mathrm{~g}$ of well ground tissue using the protocol described by Gusmini et al. (2004). DNA was extracted from young leaves of five randomly selected plants for each variety and then subsequent molecular analysis. Air dried DNA pellets were dissolved in 501 of $1 \mathrm{X}$ TE buffer (Tris-EDTA buffer- $10 \mathrm{mM}$ Tris-HCl, I mM EDTA, pH 8.0. Quantity and quality of DNA was determined by 
Nanodrop 1000 instrument (Thermo Scientific, USA) using 21 of genomic DNA. Absorbance was recorded at $260 / 280 \mathrm{~nm}$ and readings were taken for both the quantity (ng $\mu / 1)$ and quality (Absorbance). Only the samples having absorbance value from 1.90-2.00 were taken for DNA analysis. And the samples with absorbent values less are repeated till the desired amount of DNA is achieved.

\section{Selection of primers}

The DNA was amplified through polymerase chain reaction (PCR) using 60 SSR primer pairs (synthesized by Integrated DNA Technologies) previously described and used (Ahmad et al., 2003; Barkley et al., 2006; Ollitrault et al., 2010; Soriano et al., 2012; Yaly et al., 2011; Meral et al., 2011) for citrus germplasm characterization. PCR amplification of $20 \mu \mathrm{l}$ total volume was performed in $2.0 \mu \mathrm{l}$ of 10X PCR buffer, $2.5 \mu \mathrm{l}$ of $1 \mathrm{mM}$ dNTPs, $1.25 \mu \mathrm{l}$ of each of forward and reverse primer $(5 \mu \mathrm{M}), 0.25 \mu \mathrm{l}$ of Taq polymerase ( 5 units/ $\mu$ l of Promega, USA), $4.0 \mu \mathrm{l}$ of DNA (15 ng) and distilled deionized water using an Eppendorf thermal cycler. The PCR profile consisted of initial denaturation at $94{ }^{\circ} \mathrm{C}$ for $3 \mathrm{~min}$ and subsequent 35 cycles each with denaturation at $94{ }^{\circ} \mathrm{C}$ for $30 \mathrm{~s}$, primer annealing at $48-57^{\circ} \mathrm{C}$ for $1 \mathrm{~min}$ and primer extension at $72{ }^{\circ} \mathrm{C}$ for $1 \mathrm{~min}$. Final extension step was performed at $72{ }^{\circ} \mathrm{C}$ for $7 \mathrm{~min}$. Annealing temperature was modified to optimize the reaction conditions for individual primers. PCR products were stored at $4{ }^{\circ} \mathrm{C}$ before analysis. PCR-amplified DNA fragments were separated on a $1.5 \%$ agarose gel containing $1 \mathrm{X}$ TBE ( $45 \mathrm{mM}$ Tris-borate $1 \mathrm{mM}$ EDTA) and $0.5 \mu \mathrm{g} / \mathrm{ml}$ aqueous solution of ethidium bromide. The agarose gel was run at a constant voltage of $100 \mathrm{~V}$ for $2-3 \mathrm{~h}$ in $0.5 \times \mathrm{TBE}$ buffer. Gels were visualized under UV light and photographed using photo documentation system (Alphaimager system). The repeatability of the markers was verified in the whole collection and all null alleles were confirmed by a second amplification.

\section{Data collection and analysis}

SSR alleles were scored for the presence (1) and absence (0) of the SSR bands. Polymorphism information content (PIC) for each SSR marker was determined as per the procedure outlined by Senior et al. (1998).

$$
\begin{gathered}
\mathrm{PIC}=1-\Sigma(P i j)^{2} \\
i=1
\end{gathered}
$$

where $P i j$ is the frequency of $j$ th allele in $i$ th primer and summation extends over ' $\mathrm{n}$ ' patterns.

Genetic similarity coefficients between various genotypes (in pair-wise comparisons) were calculated from the SSR data matrix using dice coefficient and the resulting genetic similarity matrix was analyzed using NTSYS-PC version 2.02 to produce an agglomerative hierarchical classification (Rohlf, 1989) by employing Unweighted Pair Group Method using Arithmetic Averages (UPGMA). For estimating the similarity matrix, null alleles (no SSR allele in a given citrus genotype) were treated as missing data to reduce the biased genetic or similarity measures (Warburton and Crossa, 2000).

Genetic diversity (GD) was calculated according to the following formula of Nei (1987): 


$$
G D=n\left(1-p^{2}\right) /(n-1)
$$

where $(n)$ is the number of samples and $(p)$ is the frequency of one allele.

\section{Results and discussion}

\section{Clustering studies based on morphological diversity}

Grapefruit and tangelo varieties consist of four clusters (Fig. 1), cluster I consists of only one variety Flame with an average distance of $0.37 \mathrm{~cm}$ (Table 2) from other varieties. Cluster II consists of two varieties namely Marsh and Red Blush, which are more associated with each other with an average distance of $0.10 \mathrm{~cm}$. While in cluster III there were four varieties namely Foster, Ray Ruby, Star Ruby and Rio Red. Foster have an average distance of $0.13 \mathrm{~cm}$ as compared to Rio Red which has $0.24 \mathrm{~cm}$ distance from the other varieties. In cluster IV there were three verities Ruby Red, Minneola and Pearl. Minneola and Pearl were closely associated with each other with an average distance of $0.25 \mathrm{~cm}$ while Ruby Red have less association with other varieties with an average distance of $1.37 \mathrm{~cm}$ from other varieties. Further, the study on inheritance of agronomic traits of citrus reports them to be controlled by multiple genes which can be assessed only through morphological assessment (Liu and Deng, 2007).

Table 2. Root mean-square distance between grapefruit and tangelo varieties within clusters based on morphological characteristics.

\begin{tabular}{c|c|c|c|c}
\hline $\begin{array}{c}\text { Number of } \\
\text { clusters }\end{array}$ & \multicolumn{2}{|c|}{ Clusters joined } & Freq & $\begin{array}{c}\text { Norm RMS } \\
\text { distance (cm) }\end{array}$ \\
\hline 9 & Ray Ruby & Star Ruby & 2 & 0.0136 \\
8 & Marsh & Red Blush & 2 & 0.1072 \\
7 & Foster & CL9 & 3 & 0.1349 \\
6 & CL7 & Rio Red & 4 & 0.2447 \\
5 & Minneola & Pearl & 2 & 0.2573 \\
4 & Flame & CL8 & 3 & 0.3715 \\
3 & CL4 & CL6 & 7 & 0.5285 \\
2 & Ruby Red & CL5 & 3 & 0.7395 \\
1 & CL3 & CL2 & 10 & 1.3799 \\
\hline
\end{tabular}

However, Dorji and Yapwattanaphun (2011) concluded that the groups diverged having similarity coefficient of 0.79 in contrast to 0.41 . There is not much variation with respect to qualitative characters of the groups. Golein et al. (2005) reported that the analyzed accessions having high average similarity coefficient (0.91) indicated that all mandarins represented variations of single clones. Likewise, analysis of 43 morphological characters in the 22 cultivars of $C$. sinensis revealed that maximum similarity (0.64) occurred between the cultivars Campbell Valencia and Vanale, both of which are exotic in origin and are most similar in terms of qualitative fruit, leaf and seed characters (Malik et al., 2012). Minimum similarity (0.18) was observed between the 
cultivars Washington navel and Mosambi, which may be attributed to their different centres of origin where they have developed their distinct characters.

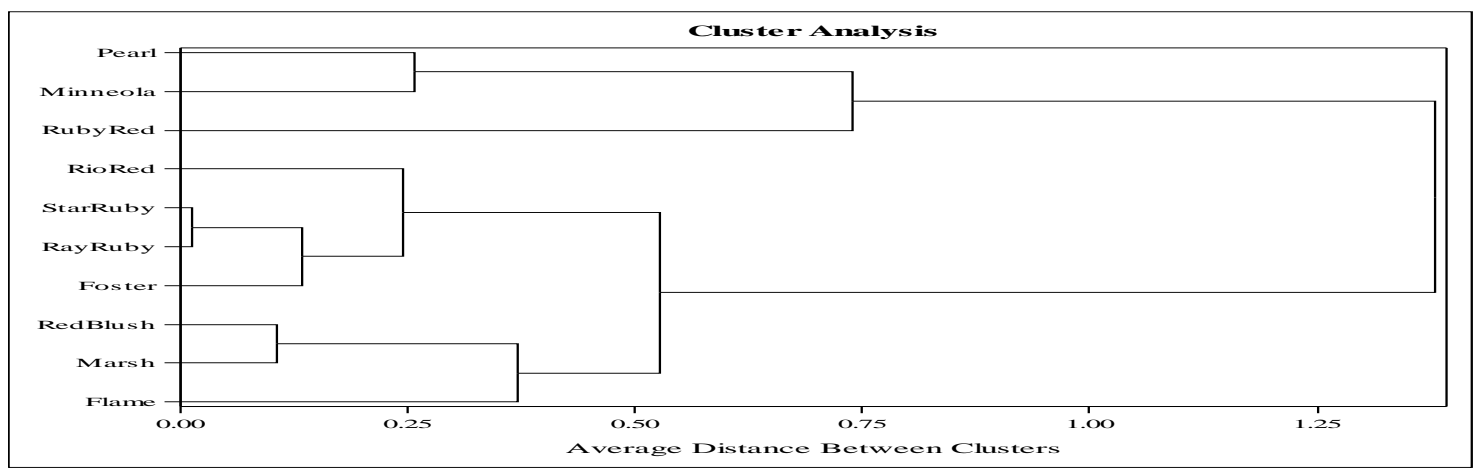

Figure 1. Dendrogram of grapefruit and tangelo varieties based on morphological characteristics using the UPGMA method

\section{Variability, heritability and genetic advance in grapefruit and tangelo varieties based on morphological characteristics.}

Estimation of genotype for phenotypic variance (PV) and genotypic variance (GV) indicated that variance was recorded maximum for number of fruits per tree, fruit weight, and fruit diameter, number of seeds per fruit and seed weight (Table 3). The variation present in population is due to genotypic and environmental effects. It includes both genotypic and environmental condition. The highest phenotypic co-efficient variance $(\mathrm{PCV})$ and genotypic co-efficient variance $(\mathrm{GCV})$ were recorded for seed weight (104.4 and 103.7, respectively), number of seeds per fruit (102.3 and 101.9, respectively), number of fruits per tree (60.0 and 60.0, respectively) and acidity (40.4 and 38.8, respectively). These mentioned characters were much more influenced by the environment than other characters.

In the present investigation of genetic advance coupled with high heritability was observed for seed weight, number of seeds per fruit, number of fruits per tree and acidity. Thus the results indicated that selection would be highly effective for above mentioned characters. Similar finding was made by Baswal et al. (2016), who concluded that the co-efficient of variation (both genotypic and phenotypic) was higher for the characters like density of oil glands $/ \mathrm{cm}^{2}$ (35.1 and 34.8 , respectively) followed by albedo thickness (19.5 and 19.4, respectively). GCV associated with high heritability ( $80 \%$ or more) indicated that selection would be effective for the improvement of these characters. Also Roy et al. (2014) concluded that in pummelo germplasm while studying variability, a wide range of variability was observed for almost all variables or characters. The co-efficient of variation was higher $(>20)$ for characters like yield per plant, fruit rind thickness, seed weight and number of fruits per plant.

Burton (1952) observed that if GCV associated with high heritability (80\% or more) indicated that selection would be effective for the improvement of these characters but if a character with low heritability ( $40 \%$ or less) selection may be comparatively difficult or virtually impractical due to masking effect of the environment on the genotypic effects. This indicated that selection for density of oil glands, albedo thickness, fruit weight and fruit diameter would be effective. In a similar study, Panse 
(1957) suggested that a high genetic advance coupled with high heritability may be expected if heritability is mainly due to additive genetic effects.

Table 3. Variability, heritability and genetic advance in grapefruit and tangelo varieties based on morphological characteristics

\begin{tabular}{|c|c|c|c|c|c|c|}
\hline Characters (Grapefruit) & PV & GV & PCV & GCV & $\begin{array}{c}\mathbf{h}^{2} \\
(\%)\end{array}$ & $\begin{array}{l}\text { GA }(\%) \\
\text { of mean }\end{array}$ \\
\hline Leaf lamina length (mm) & 79.5 & 63.4 & 8.4 & 7.5 & 79.7 & 13.9 \\
\hline Leaf lamina width (mm) & 42.4 & 28.1 & 9.6 & 7.8 & 66.3 & 13.2 \\
\hline Rootstock bud circumference $(\mathrm{cm})$ & 148.3 & 145.4 & 12.5 & 12.3 & 97.9 & 25.2 \\
\hline Leaf area & 16.1 & 14.3 & 14.8 & 13.9 & 88.5 & 27.1 \\
\hline Scion truck circumference & 216.9 & 212.5 & 16.5 & 16.4 & 97.9 & 33.4 \\
\hline Average number of seeds per fruit & 193.9 & 192.1 & 102.3 & 101.9 & 99.0 & 209.0 \\
\hline Seed weight per fruit (g) & 190.7 & 189.4 & 104.1 & 103.7 & 99.3 & 213.0 \\
\hline Seed length (mm) & 7.8 & 6.8 & 18.2 & 16.9 & 86.8 & 32.5 \\
\hline Seed width (mm) & 1.5 & 1.4 & 17.9 & 17.2 & 92.3 & 34.1 \\
\hline Flower diameter (mm) & 5.5 & 4.0 & 7.0 & 6.0 & 73.3 & 10.6 \\
\hline Staminate (\%) & 3.0 & 2.9 & 26.4 & 25.7 & 94.7 & 51.6 \\
\hline Perfect (\%) & 4.4 & 2.3 & 2.2 & 1.6 & 52.9 & 2.4 \\
\hline Pollen viability $(\%)$ & 150.2 & 145.6 & 20.2 & 19.8 & 96.9 & 40.3 \\
\hline Pollen germination & 47.9 & 45.8 & 17.5 & 17.1 & 95.5 & 34.5 \\
\hline Fruit diameter (mm) & 246.6 & 235.7 & 16.2 & 15.9 & 95.5 & 32.0 \\
\hline Fruit length (mm) & 110.8 & 102.3 & 12.0 & 11.5 & 92.3 & 22.9 \\
\hline Fruit rind thickness (mm) & 3.6 & 3.2 & 24.3 & 22.7 & 87.1 & 43.7 \\
\hline Number of segments per fruit & 13.0 & 8.9 & 23.7 & 19.5 & 68.1 & 33.2 \\
\hline Diameter of fruit axis (mm) & 13.8 & 11.8 & 27.9 & 25.8 & 85.3 & 49.2 \\
\hline Total soluble solids (\%) & 0.4 & 0.3 & 8.4 & 6.9 & 67.1 & 11.7 \\
\hline Acidity (\%) & 0.1 & 0.1 & 40.4 & 38.8 & 92.1 & 76.7 \\
\hline $\mathrm{Ph}$ & 0.1 & 0.0 & 8.8 & 5.4 & 37.1 & 6.7 \\
\hline VIT C & 59.1 & 50.4 & 17.5 & 16.2 & 85.2 & 30.8 \\
\hline JUICE \% & 66.2 & 56.2 & 15.9 & 14.7 & 84.8 & 27.9 \\
\hline PEEL \% & 18.2 & 9.0 & 13.7 & 9.6 & 49.2 & 13.9 \\
\hline RAG $\%$ & 42.4 & 19.0 & 36.4 & 24.4 & 44.8 & 33.6 \\
\hline Number fruits per tree & 22200.2 & 22161.3 & 60.0 & 60.0 & 99.8 & 123.5 \\
\hline Fruit weight (g) & 12060.5 & 11900.6 & 30.8 & 30.6 & 98.6 & 62.7 \\
\hline
\end{tabular}

$\mathrm{PV}=$ phenotypic variance, $\mathrm{GV}=$ genotypic variance, $\mathrm{PCV}=$ phenotypic coefficient of variance, $\mathrm{GCV}=$ genotypic coefficient of variance, $\mathrm{h}^{2}=$ heritability in broad sense and $\mathrm{GA}=$ genetic advances

\section{Allele amplification in grapefruit and tangelo varieties}

Allele frequency or the frequency at which alleles are found at any locus of interest is used to estimate the frequency of given genetic profile. In grapefruit and tangelo varieties a total of 75 alleles were amplified by 26 polymorphic SSR loci and the number of alleles ranged from 1 to 4 with an average of 2.88 alleles per locus. The highest number of alleles per locus was four as amplified by CAT01, CS05, CCSM204, 
CCSM70, CIBE5156, ATC09 and CMS26 followed by three alleles per locus each by CCSM77, CCSM156, CL11, OP29, CMS46, CMS09, CIBE4728, CMS3O and AG14 and the remaining markers amplified two alleles (Table 4).

Table 4. Number of alleles amplified, polymorphism (\%), polymorphic information content (PIC) value and genetic diversity of SSR markers in grapefruit and tangelo varieties

\begin{tabular}{c|c|c|c|c|c|c|c}
\hline S. no. & SSR marker & $\begin{array}{c}\text { Monomorphic } \\
\text { allele }\end{array}$ & $\begin{array}{c}\text { Polymorphic } \\
\text { allele }\end{array}$ & $\begin{array}{c}\text { Total no. } \\
\text { of alleles }\end{array}$ & $\begin{array}{c}\text { Polymorphism } \\
(\mathbf{\%})\end{array}$ & PIC & $\begin{array}{c}\text { Genetic } \\
\text { diversity }\end{array}$ \\
\hline 1 & CS05 & 1 & 3 & 4 & 75.00 & 0.69 & 0.76 \\
2 & CCSME15 & 0 & 2 & 2 & 100.00 & 0.30 & 0.33 \\
3 & OP571 & 1 & 1 & 2 & 50.00 & 0.49 & 0.55 \\
4 & CAT01 & 1 & 3 & 4 & 75.00 & 0.75 & 0.83 \\
5 & CCSM77 & 0 & 3 & 3 & 100.00 & 0.59 & 0.65 \\
6 & CCSM156 & 1 & 2 & 3 & 66.67 & 0.61 & 0.67 \\
7 & CCSM170 & 1 & 1 & 2 & 50.00 & 0.50 & 0.55 \\
8 & CCSM201 & 1 & 1 & 2 & 50.00 & 0.28 & 0.31 \\
9 & CCSM204 & 1 & 3 & 4 & 75.00 & 0.64 & 0.71 \\
10 & CCSM68 & 0 & 2 & 2 & 100.00 & 0.43 & 0.47 \\
11 & CCSM70 & 1 & 3 & 4 & 75.00 & 0.74 & 0.82 \\
12 & CCSME15 & 0 & 2 & 2 & 100.00 & 0.18 & 0.20 \\
13 & CIBE5156 & 1 & 3 & 4 & 75.00 & 0.74 & 0.83 \\
14 & CL11 & 1 & 2 & 3 & 66.67 & 0.51 & 0.56 \\
15 & CS06 & 1 & 1 & 2 & 50.00 & 0.17 & 0.18 \\
16 & CS09 & 1 & 1 & 2 & 50.00 & 0.41 & 0.45 \\
17 & CIBE5720 & 1 & 1 & 2 & 50.00 & 0.49 & 0.55 \\
18 & GT03 & 1 & 1 & 2 & 50.00 & 0.49 & 0.55 \\
19 & ATC09 & 1 & 3 & 4 & 75.00 & 0.68 & 0.75 \\
20 & 0P29 & 1 & 2 & 3 & 66.67 & 0.38 & 0.42 \\
21 & CMS46 & 1 & 2 & 3 & 66.67 & 0.61 & 0.67 \\
22 & CMS09 & 2 & 1 & 3 & 33.33 & 0.60 & 0.67 \\
23 & CIBE4728 & 2 & 1 & 3 & 33.33 & 0.66 & 0.73 \\
24 & CMS26 & 1 & 3 & 4 & 75.00 & 0.68 & 0.75 \\
25 & CMS30 & 0 & 3 & 3 & 100.00 & 0.55 & 0.61 \\
26 & AG14 & 0 & 3 & 3 & 100.00 & 0.55 & 0.61 \\
\hline & Total & $\mathbf{2 2}$ & $\mathbf{5 3}$ & $\mathbf{7 5}$ & $\mathbf{1 8 0 8 . 3 4}$ & $\mathbf{1 3 . 7 2}$ & $\mathbf{1 5 . 1 8}$ \\
\hline & Mean & $\mathbf{0 . 8 5}$ & $\mathbf{2 . 0 4}$ & $\mathbf{2 . 8 8}$ & $\mathbf{6 9 . 5 5}$ & $\mathbf{0 . 5 3}$ & $\mathbf{0 . 5 8}$ \\
\hline & & & & & & &
\end{tabular}

\section{Polymorphic information content and percentage of polymorphism among grapefruit and tangelo varieties based on SSR markers}

In Grapefruit and tangelo varieties the percentage of polymorphism of the 26 polymorphic markers ranged from 50 to 100 (Table 4). Among these, 6 exhibited 100 percent polymorphism; seven were having $75 \%$, four having $66.66 \%$ and remaining had $50 \%$. Average polymorphism (\%) of all the polymorphic primer pairs across all the varieties of grapefruit was 69.55 . The PIC value which is a measure of allelic diversity 
at a locus ranged from 0.17 (CS06) to 0.75 (CAT01) with an average value of 0.53 . Fourteen SSR markers revealed PIC value more than 0.53. Primer CAT01 amplified 4 alleles and had the highest PIC value of 0.75 followed by CSM70 and CIBE5156 in which 3 alleles were amplified and had PIC value of 0.74 (Table 4). All the alleles amplified by CAT01 primer pairs on all the varieties of grapefruit were all distinguishable. It has been observed that marker OP29 amplified 3 alleles and had PIC value of 0.38 while GT03 amplified 2 alleles and had PIC value of 0.49 . Therefore, there seemed to be no strong correlation between the PIC value and the number of alleles amplified. Across all varieties, a total of 663 alleles (Table 5) were amplified by 58 SSR primers with an average of 63.30 alleles for each variety. The average amplified fragments for polymorphic marker was 51.90 whereas for monomorphic, it was 14.40. The maximum number of alleles (75) was detected in Ray Ruby whereas Minneola showed the least number of alleles (52). However, the percent of polymorphic markers was maximum (82.09) in Marsh followed by $81.25 \%$ in Pearl.

Table 5. Total number of alleles amplified in grapefruit and tangelo varieties using SSR markers

\begin{tabular}{|c|c|c|c|c|c|}
\hline \multirow[b]{2}{*}{ S. no. } & \multirow[b]{2}{*}{ Genotypes } & \multicolumn{2}{|c|}{ Number of amplified alleles } & \multirow[b]{2}{*}{ Total } & \multirow{2}{*}{$\begin{array}{c}\text { Polymorphism } \\
(\%)\end{array}$} \\
\hline & & $\begin{array}{l}\text { Monomorphic } \\
\text { markers }\end{array}$ & $\begin{array}{c}\text { Polymorphic } \\
\text { markers }\end{array}$ & & \\
\hline \multicolumn{6}{|c|}{ Grapefruit } \\
\hline 1 & Foster & 12 & 48 & 60 & 80.00 \\
\hline 2 & Flame & 13 & 48 & 61 & 78.69 \\
\hline 3 & Marsh & 12 & 55 & 67 & 82.09 \\
\hline 4 & Ray Ruby & 15 & 60 & 75 & 80.00 \\
\hline 5 & Red Blush & 20 & 52 & 72 & 72.22 \\
\hline 6 & Rio Red & 16 & 56 & 72 & 77.78 \\
\hline 7 & Ruby Red & 14 & 60 & 74 & 81.08 \\
\hline 8 & Star Ruby & 15 & 51 & 66 & 77.27 \\
\hline \multicolumn{6}{|c|}{ Tangelo } \\
\hline 9 & Pearl & 12 & 52 & 64 & 81.25 \\
\hline \multirow[t]{3}{*}{10} & Minneola & 15 & 37 & 52 & 71.15 \\
\hline & Total & 144 & 519 & 663 & 781.53 \\
\hline & Mean & 14.40 & 51.90 & 66.30 & 78.15 \\
\hline
\end{tabular}

Likewise, Meral et al. (2011) reported narrow genetic diversity in Satsuma mandarins clones suggesting that the observed morphological polymorphism within the group must be associated with somatic mutations which were not detected by SSR molecular markers. Similarly, Singh et al. (2016) concluded that among 19 different mandarin genotypes that 57 SSR markers amplified, a total of 96 alleles were detected by 39 polymorphic SSR loci and maximum 5 alleles were amplified with an average of 2.46 alleles per primer pair. The CAT01 was the highly informative marker as it revealed maximum number of alleles (5), PIC value (0.75) and genetic diversity (0.79). Across the genotypes, maximum number of alleles (83) was detected in Daisy hybrid and the percentage of polymorphic marker was maximum (80.32) in Nova hybrid. The markers with low number of alleles were able to differentiate the varieties with specific alleles. 
Simple Sequence Repeats (SSRs) have proven to be efficient genetic markers for comparative genetic mapping between Citrus species (Luro et al., 2008). Although some SSRs were identified based on EST database in previous studies (Chen et al., 2006) no system analysis of SSRs in citrus has been reported because of incomplete citrus genome. Recently, the Clementine mandarin genome has been sequenced (Gmitter et al., 2012) and the completion of these genome sequences provided an opportunity for us to scan the entire genome for SSR discovery in citrus. In this study, we present our results on the SSR survey for the development of citrus SSR markers.

\section{Genetic diversity}

Genetic diversity among grapefruit and tangelo varieties ranged from 0.18 (CS06) to 0.83 (CAT01 and CIBE5156). The average value of genetic diversity across all the primers was 0.58 (Table 4). The dendrogram (Fig. 2) depicting the genetic relationship classified the genotypes into 3 major clusters (I, II and III). The cluster I contains single variety (Minneola) but cluster II was further sub divided into two sub clusters IIA and IIB with three (Rio Red, Star Ruby and Pearl) and two (Flame and Foster) varieties respectively. While four (Ray Ruby, Marsh, Ruby Red and Red Blush) varieties were clustered in cluster III. The similarity coefficient based on DNA amplification of grapefruit and tangelo varieties using SSR primer was estimated by dice similarity coefficient (Table 6). The varieties Ruby Flame and Foster, Ruby Red and Red Blush showed the highest genetic similarity having coefficient of 0.90 and were closely related. However, Rio Red and Pearl showed lowest (0.68) genetic similarity coefficient and these were genetically distinct from each other. Similarly, 19 different mandarin genotypes (Singh et al., 2016) were classified in three clusters, i.e. cluster I, cluster II and cluster III. All the indigenous genotypes (selections) were grouped in cluster -I and it had maximum genetic similarity coefficient. However, the exotic genotypes (hybrids) were grouped in cluster II and cluster III. Clustering was according to the breeding history of genotypes but independent of their geographic origin.

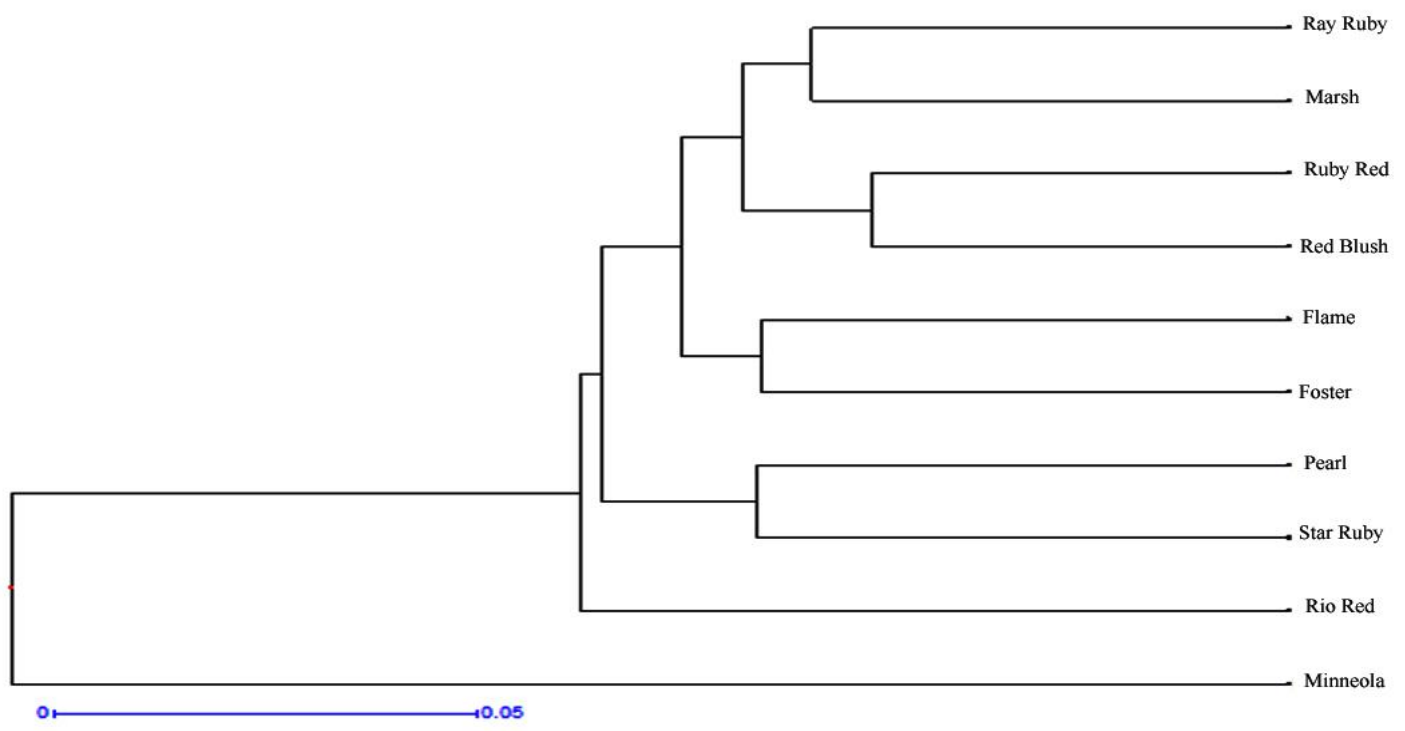

Figure 2. Dendrogram illustrating genetic relationship among grapefruit and tangelo varieties based on the SSR markers generated by UPGMA tree analysis 


$$
-5353-
$$

Table 6. Similarity coefficient based on DNA amplification of grapefruit and tangelo varieties estimated by dice similarity coefficient

\begin{tabular}{c|c|c|c|c|c|c|c|c|c}
\hline Varieties & $\mathbf{1}$ & $\mathbf{2}$ & $\mathbf{3}$ & $\mathbf{4}$ & $\mathbf{5}$ & $\mathbf{6}$ & $\mathbf{7}$ & $\mathbf{8}$ & $\mathbf{9}$ \\
\hline $\mathbf{2}$ & 0.76 & & & & & & & & \\
$\mathbf{3}$ & 0.88 & 0.71 & & & & & & & \\
$\mathbf{4}$ & 0.85 & 0.73 & 0.87 & & & & & & \\
$\mathbf{5}$ & 0.87 & 0.69 & 0.85 & 0.89 & & & & & \\
$\mathbf{6}$ & 0.83 & 0.76 & 0.83 & 0.83 & 0.86 & & & & \\
$\mathbf{7}$ & 0.82 & 0.68 & 0.82 & 0.82 & 0.85 & 0.83 & & & \\
$\mathbf{8}$ & 0.87 & 0.73 & 0.87 & 0.89 & 0.90 & 0.90 & 0.87 & & \\
$\mathbf{9}$ & 0.85 & 0.71 & 0.81 & 0.81 & 0.83 & 0.84 & 0.83 & 0.88 & \\
$\mathbf{1 0}$ & 0.86 & 0.68 & 0.82 & 0.82 & 0.84 & 0.83 & 0.84 & 0.86 & 0.87 \\
\hline
\end{tabular}

Legend: Marsh, Ray Ruby, Rio Red, Star Ruby, Flame, Red Blush, Ruby Red, Foster, Minneola, and Pearl

The results revealed that the difference in the dendrogram of morphological and molecular data could be due to action of diverse evolutionary forces and environmental attributes. This hypothesis was supported by the findings of Paudyal and Haq (2008) who reported that environmental factors affected up to $40 \%$ in pummelo accessions in an un-controlled field survey. The morphological difference in individual accession was supported by the observation of Dorji and Yapwattanaphun (2011a) who reported that phenotypic variation could be attributed to mutations, cross pollination and environmental interactions (Figs. 3, 4 and 5; Table 7).

Table 7. Physico-chemical parameters of grapefruit and tangelo varieties

\begin{tabular}{|c|c|c|c|c|c|c|c|c|c|c|c|c|}
\hline Varieties & $\begin{array}{c}\text { Average } \\
\text { number } \\
\text { of seeds } \\
\text { per fruit }\end{array}$ & $\begin{array}{c}\text { Seed } \\
\text { weight } \\
\text { per } \\
\text { fruit }(g)\end{array}$ & $\begin{array}{c}\text { Rootstock } \\
\text { diameter } \\
(\mathbf{m m})\end{array}$ & $\begin{array}{c}\text { Scion } \\
\text { diameter } \\
(\mathbf{m m})\end{array}$ & $\begin{array}{c}\text { Spine } \\
\text { length } \\
(\mathbf{m m})\end{array}$ & $\begin{array}{c}\text { Leaf } \\
\text { lamina } \\
\text { length } \\
(\mathbf{m m})\end{array}$ & $\begin{array}{c}\text { Leaf } \\
\text { lamina } \\
\text { width } \\
(\mathrm{mm})\end{array}$ & $\begin{array}{l}\text { Leaf } \\
\text { area } \\
\left(\mathrm{cm}^{2}\right)\end{array}$ & $\begin{array}{c}\begin{array}{c}\text { Petiole } \\
\text { wing } \\
\text { width } \\
(\mathrm{mm})\end{array} \\
\text { (a) }\end{array}$ & $\begin{array}{c}\text { Flower } \\
\text { diameter } \\
(\mathrm{mm})\end{array}$ & $\begin{array}{c}\text { Pollen } \\
\text { viability } \\
(\%)\end{array}$ & $\begin{array}{c}\text { Pollen } \\
\text { germination } \\
(\%)\end{array}$ \\
\hline \multicolumn{13}{|c|}{ Grapefruit } \\
\hline Flame & 3.3 & 2.3 & 94.3 & 90.1 & 5.6 & 117.6 & 76.9 & 32.7 & 12.9 & 32.8 & 51.4 & 32.9 \\
\hline Foster & 34.5 & 30.2 & 83.2 & 80.3 & 5.7 & 105.9 & 66.1 & 27.7 & 16.3 & 35.0 & 54.9 & 38.2 \\
\hline $\begin{array}{c}\text { Marsh } \\
\text { Seedless }\end{array}$ & 3.2 & 2.9 & 104.6 & 100.6 & 4.8 & 110.1 & 68.5 & 29.8 & 18.8 & 31.3 & 50.2 & 29.9 \\
\hline Ray Ruby & 4.5 & 3.6 & 110.5 & 105.1 & 4.3 & 114.2 & 74.1 & 31.6 & 22.0 & 37.1 & 55.9 & 39.7 \\
\hline Red Blush & 3.8 & 3.1 & 115.1 & 112.2 & 6.3 & 104.2 & 64.7 & 25.3 & 15.6 & 33.1 & 57.6 & 40.4 \\
\hline Rio Red & 1.8 & 1.1 & 108.0 & 96.1 & 5.1 & 99.1 & 65.2 & 23.9 & 17.8 & 31.6 & 53.2 & 36.6 \\
\hline Ruby Red & 3.5 & 3.3 & 87.3 & 74.1 & 5.5 & 97.0 & 73.3 & 23.1 & 14.5 & 35.6 & 53.5 & 34.7 \\
\hline Star Ruby & 35.8 & 33.1 & 79.5 & 65.6 & 4.3 & 110.9 & 63.3 & 30.4 & 19.8 & 34.0 & 66.7 & 42.4 \\
\hline \multicolumn{13}{|c|}{ Tangelo } \\
\hline Minneola & 21.5 & 24.7 & 92.0 & 80.1 & 3.4 & 101.7 & 61.1 & 24.5 & 23.3 & 30.4 & 77.7 & 46.9 \\
\hline Pearl & 24.0 & 28.3 & 98.7 & 84.5 & 3.6 & 90.7 & 60.0 & 21.7 & 20.7 & 32.2 & 85.7 & 53.0 \\
\hline $\mathrm{SEm} \pm$ & 2.3 & 1.9 & 1.0 & 1.2 & 0.6 & 6.9 & 6.5 & 2.4 & 0.9 & 2.1 & 3.7 & 2.5 \\
\hline $\begin{array}{c}\text { LSD } \\
(p=0.05)\end{array}$ & 0.8 & 0.7 & 3.0 & 3.6 & 0.2 & 2.3 & 2.2 & 0.8 & 0.3 & 0.7 & 1.2 & 0.8 \\
\hline
\end{tabular}




$$
\text { - } 5354 \text { - }
$$

\begin{tabular}{|c|c|c|c|c|c|c|c|c|c|c|c|c|}
\hline Varieties & $\begin{array}{c}\text { Fruit } \\
\text { diameter } \\
(\mathbf{m m})\end{array}$ & $\begin{array}{c}\text { Fruit } \\
\text { length } \\
(\mathrm{mm})\end{array}$ & $\begin{array}{c}\text { Fruit rind } \\
\text { thickness } \\
(\mathbf{m m})\end{array}$ & \begin{tabular}{|c|}
$\begin{array}{c}\text { Number } \\
\text { of } \\
\text { segments } \\
\text { per fruit }\end{array}$ \\
\end{tabular} & $\begin{array}{c}\text { Total } \\
\text { soluble } \\
\text { solids } \\
\text { (Brix) }\end{array}$ & $\begin{array}{c}\text { Acidity } \\
(\%)\end{array}$ & $\mathbf{p H}$ & $\begin{array}{c}\text { Ascorbic } \\
\text { acid } \\
(\mathbf{m g} / \mathbf{1 0 0 g})\end{array}$ & $\begin{array}{c}\text { Juice } \\
\text { content } \\
(\%)\end{array}$ & $\begin{array}{c}\text { Peel } \\
\text { content } \\
(\%)\end{array}$ & $\begin{array}{c}\text { Rag } \\
\text { content } \\
(\%)\end{array}$ & $\begin{array}{c}\text { Fruit } \\
\text { weight }(g)\end{array}$ \\
\hline \multicolumn{13}{|c|}{ Grapefruit } \\
\hline Flame & 93.0 & 83.7 & 7.2 & 12.8 & 7.3 & 1.13 & 4.1 & 52.9 & 52.3 & 34.9 & 12.8 & 258.9 \\
\hline Foster & 99.1 & 91.3 & 8.5 & 15.4 & 8.7 & 0.90 & 4.2 & 40.9 & 45.6 & 33.4 & 21.2 & 431.9 \\
\hline $\begin{array}{c}\text { Marsh } \\
\text { Seedless }\end{array}$ & 103.1 & 93.9 & 8.5 & 12.6 & 7.5 & 1.45 & 4.5 & 54.7 & 46.8 & 32.8 & 20.5 & 337.1 \\
\hline Ray Ruby & 111.6 & 96.9 & 7.7 & 14.4 & 7.9 & 1.80 & 5.0 & 50.9 & 48.4 & 31.3 & 20.2 & 384.0 \\
\hline Red Blush & 84.9 & 75.9 & 10.4 & 13.7 & 8.2 & 0.62 & 4.8 & 35.8 & 51.9 & 31.5 & 16.6 & 313.7 \\
\hline Rio Red & 114.4 & 98.8 & 9.7 & 15.4 & 8.2 & 1.16 & 4.4 & 41.5 & 44.0 & 32.1 & 23.9 & 456.5 \\
\hline Ruby Red & 109.1 & 97.5 & 9.3 & 13.0 & 8.5 & 1.03 & 4.8 & 43.9 & 40.4 & 34.4 & 25.2 & 561.8 \\
\hline Star Ruby & 104.9 & 87.0 & 7.5 & 13.5 & 8.0 & 0.78 & 4.3 & 46.6 & 53.7 & 30.7 & 15.6 & 359.4 \\
\hline \multicolumn{13}{|c|}{ Tangelo } \\
\hline Minneola & 70.5 & 68.0 & 4.4 & 19.5 & 9.4 & 0.54 & 4.7 & 36.9 & 64.3 & 26.7 & 9.0 & 203.6 \\
\hline Pearl & 74.0 & 81.1 & 5.6 & 22.3 & 8.4 & 0.64 & 4.8 & 34.0 & 62.5 & 23.7 & 13.8 & 236.2 \\
\hline $\mathrm{SEm} \pm$ & 5.7 & 5.0 & 1.2 & 3.5 & 0.7 & 0.19 & 0.6 & 5.1 & 5.5 & 5.3 & 8.4 & 21.9 \\
\hline $\begin{array}{c}\text { LSD } \\
(\mathrm{p}=0.05)\end{array}$ & 1.9 & 1.7 & 0.4 & 1.2 & 0.2 & 0.07 & 0.2 & 1.7 & 1.8 & 1.8 & 2.8 & 7.3 \\
\hline
\end{tabular}
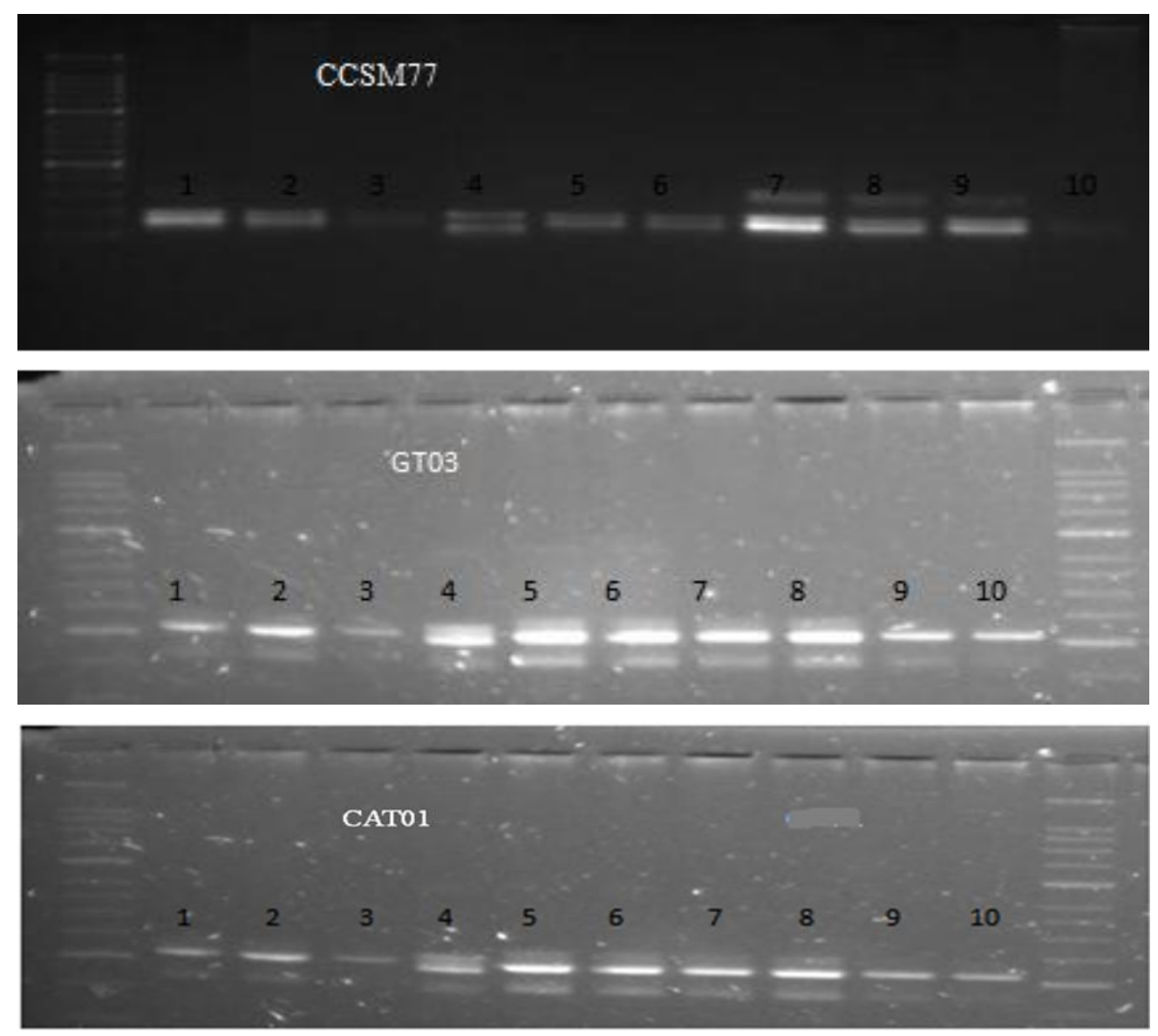

Figure 3. Agarose gel showing SSR amplification profile by different primer in different grapefruit and tangelo varieties Flame, Foster, Marsh, Ray Ruby, Red Blush, Rio Red, Ruby Red, Star Ruby, Minneola and Pear 


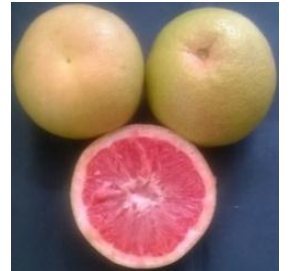

Ray Ruby

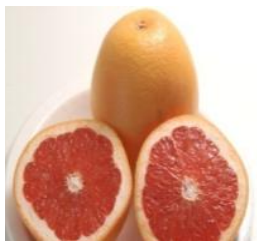

Flame

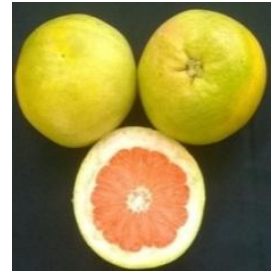

Red Blush

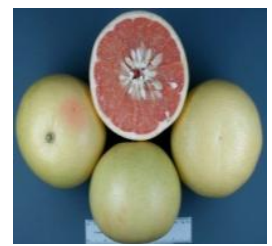

Foster

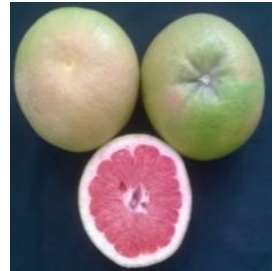

Rio Red

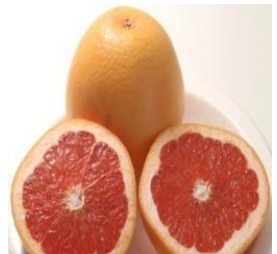

Star Ruby

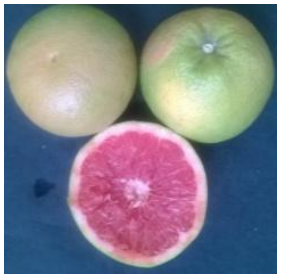

Ruby Red

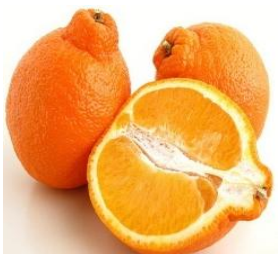

Minneola

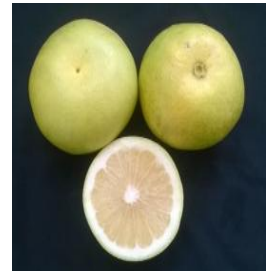

Marsh Seedless

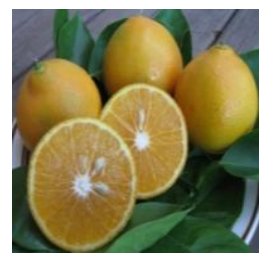

Pearl

Figure 4. Diversity in fruit size and shape of different grapefruit and tangelo varieties

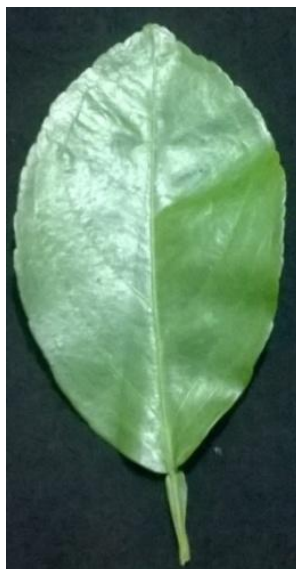

Marsh

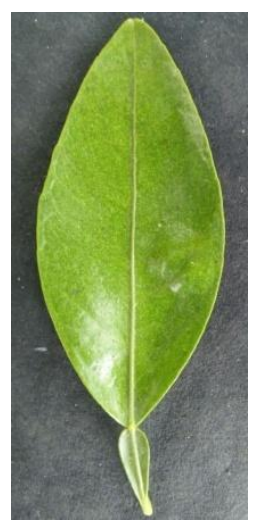

Minneola

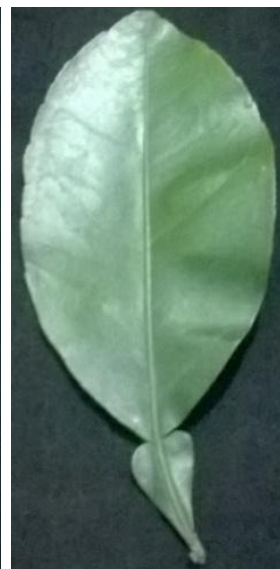

Ray Ruby

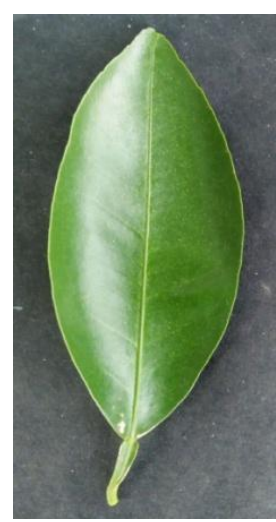

Pearl

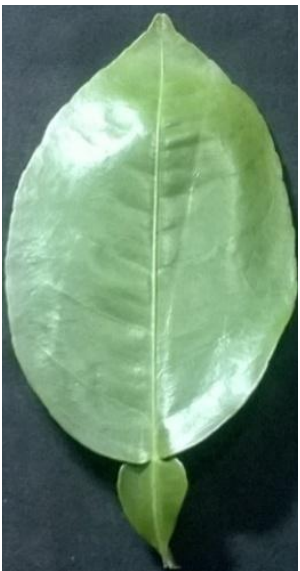

Red Blush

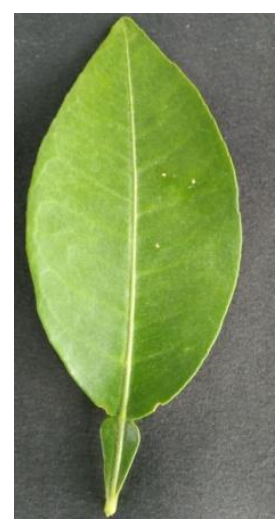

Foster

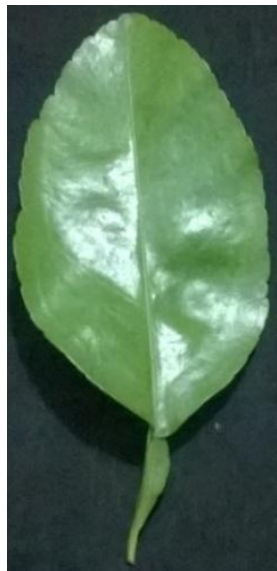

Rio Red

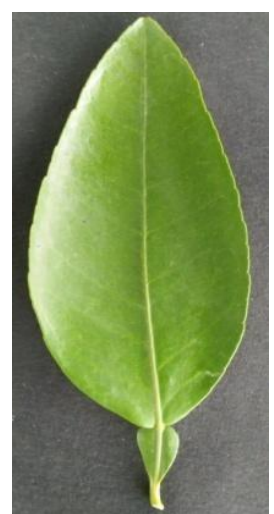

Flame

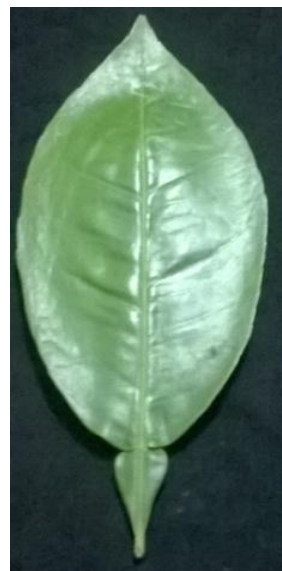

Ruby Red

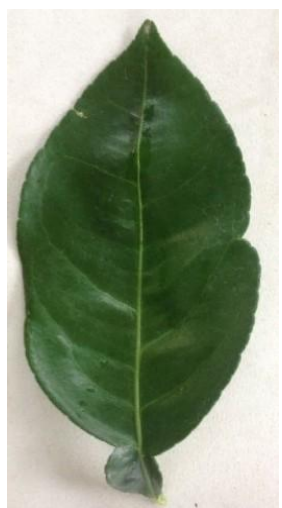

Star Ruby

Figure 5. Diversity in leaf size and shape of different grapefruit and tangelo varieties

\section{Conclusions}

Present study indicated that genetic diversity in grapefruit and tangelo varieties was found to be very low, despite having high morphological variability, which could be elucidated by the fact that much of the phenotypic variation witnessed may be due to 
somatic mutations. Genetic diversity among grapefruit and tangelo varieties ranged from 0.18 (CS06) to 0.83 (CAT01 and CIBE5156). Furthermore, based on molecular analysis, varieties Ruby Flame and Foster, Ruby Red and Red Blush showed the highest genetic similarity having coefficient of 0.90 and were closely related. However, Rio Red and Pearl showed the lowest (0.68) genetic similarity coefficient and these were genetically distinct from each other.

Acknowledgements. The first author is thankful to the Department of Science and Technology, New Delhi, India for providing INSPIRE fellowship during this study.

\section{REFERENCES}

[1] Ahmad, M., Javaid, A., Rahman, H., Hussain, S. I., Ramzan, A., Ghafoor, A. (2012): Identification of mandarin $\mathrm{x}$ orange hybrids using simple sequence repeat markers. - $\mathbf{J}$ Agric Res. 50: 225-232.

[2] Ahmad, R., Struss, D., Southwick, S. M. (2003): Development and characterization of micro satellite markers in citrus. - J Amer Soc Hort Sci 128: 584-90.

[3] Allard, R. W. (1960): Principles of Plant Breeding. - John Wiley and Sons Inc., New York, United States of America, pp. 83-108.

[4] Amara, M. H., Biswasa, M. K., Zhangc, Z., Guoa, W. W. (2011): Exploitation of SSR, SRAP and CAPS-SNP markers for genetic diversity of citrus germplasm collection. - Sci Horti 128: 220-227.

[5] Anonoymus (1999): IPGRI. Descriptors of Citrus. - International Plant Genetic Resource Institute. Rome. Italy. http:/www.cgiar.org/ipgri/.

[6] Barkley, N. A., Roose, M. L., Krueger, R. R., Federici, C. T. (2006): Assessing genetic diversity and population structure in a citrus germplasm collection utilizing simple sequence repeat markers (SSRs). - Theor Appl Genet 112: 1519-31.

[7] Baswal, A. K., Rattanpal, H. S., Sidhu, G. S. (2016): Varietal assessment and variability studies in grapefruit (citrus paradisi aradisi aradisi mac fadyen) genotypes in subtropical zones of Punjab al zones of Punjab, India. - The Bioscan 11(2): 1369-71.

[8] Burton, G. W. (1952): Quantitaive inhereitance in grasses. - Proc. 6th Intercropping. Grassland Cong., Pp. 277-283.

[9] Burton, G. W., Vane, E. W. (1953): Estimating herita-bility in tall fescue (Festuca arundinacea) from replicated clone material. - Agron J 45: 475-81.

[10] Chen, C., Zhou, P., Choi, Y. A., Huang, S., Gmitter, Jr. F. G. (2006): Mining and characterizing microsatellites from citrus ESTs. - Theoretical and Applied Genetics 112: 1248-1257.

[11] Chidambara, Murthy, K. N., Jayaprakasha, G. K., Kumar, V., Rathore, K. S., Patil, B. S. (2011): Citrus limonin and its glucoside inhibit colon adenocarcinoma cell proliferation through apoptosis. - J Agri Food Chem 59: 2314-2323.

[12] Chowdhury, N. H. (1991): Studies on Quality of Rice in Bangladesh. - In: Proceeding of the Workshop on Chemical Aspects of Rice Grain Quality, IRRI, Philippines, pp. 23-127.

[13] Corazza-Nunes, M. J., Machado, M. A., Nunes, W. M. C., Cristofani, M., Targon, M. L. P. N. (2002): Assessment of genetic variability in grapefruits (Citrus paradisi Macf.) and pummelos (C. maxima Burm. Merr.) using RAPD and SSR markers. - Euphytica 126: 169-76.

[14] Dorji, K., Yapwattanaphun, C. (2011): Morphological identification of mandarin (Citrus reticulata Blanco) in Bhutan. - Kasetsart J Nat Sci 45: 793-802.

[15] Fang, D. Q., Roose, M. L. (1997): Identification of closely related Citrus cultivars with inter simple sequence repeat markers. - Theor Appl Genet 95: 408-17. 
[16] Gmitter, Jr. F. G., Chen, C., Machado, M. A., Souza, A. A., Ollitrault, P. (2012): Citrus genomics. - Tree Genetics \& Genomes 8: 611-626.

[17] Golein, B., Talaie, A., Zamani, Z., Eabadi, A., Behjatnia, A. (2005): Assessment of Genetic Variability in Some Iranian Sweet Oranges (Citrus sinensis [L.] Osbeck) and Mandarins (Citrus reticulata Blanco) Using SSR Markers. - International Journal of Agriculture \& Biology 7(2): 167-170.

[18] Golein, B., Fifaei, R., Ghasemi, M. (2011): Identification of zygotic and nucellar seedlings in citrus interspecific crosses by inter simple sequence repeats (ISSR) markers. - Afr J Biotechnol 10: 18965-18970.

[19] Gulsen, O., Roose, M. L. (2001): Lemons: diversity and relationships with selected Citrus genotypes as measured with nuclear genome markers. - J Amer Soc Hort Sci. 126: 309327.

[20] Gusmini, G., Wehner, T., Jarret, R. (2004): Inheritance of egusi seed type in watermelon. - J. Hered. 95: 268-270.

[21] Jianfeng, H., Yonghua, Q., Hongxia, M., Chunyan, Z., Zixing, Ye., Guibing, Hu. (2012): Molecular marker analysis of 'Shatangju' and 'Wuzishatangju' mandarin (Citrus reticulata Blanco). - Afr J Biotechnol 11: 15501-15509.

[22] Johnson, H. W., Robinson, H. F., Comstock, R. E. (1955): Estimates of genetics and environmental variability in soyabean. - Agron J 47: 314-18.

[23] Liu, Y. Z., Dang, X. X. (2007): Citrus breeding and genetics in China. - The Asian Australian J Plant Sci Biotechnol pp. 23-28.

[24] Luro, F., G. Costantino, J., Terol, X., Argout, T., Allario, P., Wincker, M., Talon, P., Ollitrault, R. Morillon. (2008): Transferability of the EST-SSRs developed on Nules clementine (Citrus clementina Hort ex Tan) to other citrus species and their effectiveness for genetic mapping. - BMC Genomics 9: 287.

[25] Malik, S. K., Rohini, M. R., Kumar, S., Choudhary, R., Pal, D., Chaudhury, R. (2012): Assessment of genetic diversity in sweet orange [Citrus sinensis (L.) Osbeck] cultivars of India using morphological and RAPD markers. - Agric Res 1: 317-24.

[26] Marak, C. K., Laskar, M. A. (2010): Analysis of phonetic relationship between Citrus indica Tanaka and a few commercially important citrus species by ISSR markers. - Sci Hortic124: 345-348.

[27] Meral, N., Tuzcu, O., Yeilolu, T., Kacar, Y. A., Yildirim, B., Boncuk, M., Cimen, B. (2011): Molecular diversification and preliminary evaluations of some Satsuma selections performance under Mediterranean conditions. - Afri J Biotech 10: 4347-57.

[28] Moore, G. A. (2001): Oranges and lemons: clues to the taxonomy of Citrus from molecular markers. - Trends Genet 17(9): 536-40.

[29] Nei, M. (1987): Molecular Evolutionary Genetics. - Columbia University Press, New York.

[30] NHB (2016): Fruit Production Database. - National Horticulture Board, New Delhi, India. www.nhb.in.

[31] Okunowo, W., Oyedeji, O., Afolabi, L., Matanmi, E. (2013): Essential oil of grapefruit (Citrus paradisi) peels and its antimicrobial activities. - Amr J Plant Sci 4: 1-9.

[32] Ollitrault, F., Terol, J., Pina, J., Navarro, A., Talon, L., Ollitrault, P. (2010): Development of SSR markers from Citrus clementina (Rutacea) BAC end sequences and interspecific transferability in citrus. - Amer J Bot 124e-29 e.

[33] Panse, V. G. (1957): Genetics of quantitative characters in selections to plant breeding. Ind Jour Genet 17: 318-28.

[34] Paudyal, K., Haq, N. (2008): Variation of pomelo [Citrus grandis (L.) Osbeck] in Nepal and participatory selection of strains for further improvement. - Agroforestry Systems 72: 195-204.

[35] Platt, R. (2000): Current concepts in optimum nutrition for cardio vascular disease. - Prev Cardiol 3: 83-87. 
[36] Rabha, A., Wangchu, L., and Singh, B. (2013): Studies on genetic diversity of citrus in east Siang district of Arunachal Pradesh. - Int J Agric Environ Biotech 6: 131-37.

[37] Rangana, S. (1986): Hand Book of Analysis and Quality Control for the Fruit and Vegetable Products. - Tata McGraw Hills, New Delhi.

[38] Reuther, E., Batcheler, L. D., Webber, H. J. (1967): The Citrus Industry. Vol. 1. - Agr. Sci. University of California, Berkeley.

[39] Rohlf, F. J. (1989): NTSYS-pc Numerical Taxonomy and Multivariate Analysis System, version 2.02. - Exeter Publication, Sarauket, NY.

[40] Roy, D., Kundu, S., Ghosh, B., Dutta, P., Pal, R. (2014): Performance of pummelo germplasm in new alluvial zone of West Bengal. - J Crop Weed 10: 179-82.

[41] Scora, R. W. (1988): Biochemistry, Taxonomy and Evolution of Modern Cultivated Citrus. Proc Int Soc Citricult VI. Congr. vol. 1. - Margraf Publishers, Weikersheim, Germany, pp. 277-289.

[42] Scora, R. W., Kumamoto, J., Soost, R. K., and Nauer, E. M. (1982): Contribution to the origin of the Grapefruit, Citrus paradisi (Rutaceae). - Syst Bot 7: 170-77.

[43] Senior, M. L., Murphy, J. P., Goodman, M. M., Stuber, C. W. (1998): Utility of SSRs for determination genetic similarities and relationship in maize using an agarose gel system. - Crop Sci 38: 1088-98.

[44] Shahsavar, A. R., Izadpanah, K., Tafazoli, E., Tabatabaei, B. E. S. (2007): Characterization of Citrus germplasm including unknown variants by inter-simple sequence repeat (ISSR) markers. - Sci Hortic 112: 310-314.

[45] Silver, H. J., Dietrich, M. S., Niswender, K. D. (2011): Effects of grapefruit, grapefruit juice and water preloads on energy balance, weight loss, body composition, and cardio metabolic risk in free-living obese adults. - Nutri Metabol 8: 8.

[46] Singh, P., Singh, A., Navraj K, S., Sidhu G, S., Rattanpal, H. S. (2016a): Genetic diversity and DNA fingerprinting of indigenous and exotic mandarin genotypes in India using SSR markers. - Aus J Crop Sci 10(1): 24-31.

[47] Singh, P., Singh, A., Rattanpal, H. S. (2016b): Genetic divergence of indigenous and exotic mandarin (Citrus reticulata Blanco) accessions based on fruit morphological and physiological traits. - Res Crops 17(3): 538-44.

[48] Soriano, J., Zuriage, E., Rubio, P., Llacer, G., Infante, R., Badenes, M. (2012): Development and characterization of microsatellite markers in pomegranate (punica granatum L). - Mol Breed 27: 119-28.

[49] Uzun, A., Yesiloglu, T. (2012): Genetic Diversity in Citrus. - In: Caliskan, M. (ed.) Genetic Diversity in Plants. InTech, London. http://www.intechopen.com/books/geneticdiversity-inplants/genetic-diversity-in-citrus.

[50] Uzun, A., Gulsen, O., Kafa, G., Seday, U., Tuzcu, O., Yesiloglu, T. (2009): Characterization for yield, fruit quality, and molecular profiles of lemon genotypes tolerant to 'mal secco' disease. - Sci Hortic.122: 556-561.

[51] Warburton, M., Crossa, J. (2000): Data Analysis in the CIMMYT Applied Biotechnology Centre for Fingerprinting and Genetic Diversity Analysis. - CIMMYT, Texcoco, Mexico.

[52] Yaly, M. C., Novelli, V. M., Bastianel, M., Machado, M. A. (2011): Transferability and level of heterozygosity of microsatellite markers in citrus species. - Plant Mol Biol Rep 29: 418-23. 